\title{
RANKING OF EU NATIONAL BANKING SYSTEMS USING MULTI-CRITERIA ANALYSIS IN THE LIGHT OF BREXIT
}

\author{
Magdalena RADULESCU - Aleksandra FEDAJEV - Djordje NIKOLIC
}

(Received: 25 January 2017; revision received: 27 April 2017; accepted: 8 July 2017)

\begin{abstract}
In order to define and implement the most effective measures to overcome the difficulties of the post-crisis period, the policy-makers of ECB must identify not just main weaknesses of each banking system, but their strong points also. This requires the application of multi-criteria analysis, considering that policy-makers need to take into account a number of different aspects that, on the whole, indicate the quality of the banking system. Our aim is a comparative analysis of European banking systems right after the Brexit moment and within the framework of the tight new Basel III regulations. In this paper, we have ranked the banking systems of the $28 \mathrm{EU}$ member states using multi-criteria analysis, specifically the PROMETHEE II method. The use of the PROMETHEE II method in combination with the entropy method offers a comprehensive insight into the banking system of each member state, given that the observed countries are ranked according to 9 conflicting criteria that are mostly used in banking system analysis. Our analysis shows that the banking systems in Central and Eastern Europe are the best performers, while the EMU's developed banking systems such as the German, Italian, British, and French one are positioned among the last ranked. The Portuguese and Greek banking systems are, as expected, ranked in the last positions in our list. The obtained results also pointed out that the ECB should change its approach to the management and further development of a European Banking Union.
\end{abstract}

Keywords: multi-criteria analysis, PROMETHEE method, entropy method, European Union, banking systems, Brexit, European banking crisis, European Central Bank, European Banking Union

JEL classification indices: $\mathrm{C} 10, \mathrm{C} 82, \mathrm{G} 21$

Magdalena Radulescu, corresponding author. Associate Professor at the Faculty of Economic Studies, University of Pitesti, Romania. E- mail: youmagdar@yahoo.com

Aleksandra Fedajev, Assistant Professor at the Technical Faculty in Bor, University of Belgrade, Serbia. E-mail: afedajev@tf.bor.ac.rs

Djordje Nikolic, Assistant Professor at the Technical Faculty in Bor, University of Belgrade, Serbia. E-mail: djnikolic@tfbor.bg.ac.rs 


\section{INTRODUCTION}

The Basel III Accord will greatly impact the European banking sector. The new regulations request additional Tier 1 capital, short-term liquidity, and long-term funding. It seems that the existing gaps are greater in Europe than in the US. Closing them will have a substantial impact on profitability. Basel III will reduce return on equity (ROE) for the average bank by about 4 percentage points in Europe from the pre-crisis level of 15 percent. Banks are already seeking to manage ROE in the new environment by cutting costs and adjusting prices (Härle et al. 2010).

After the crisis, the regulatory developments and the current low interest rate pose challenges. In some countries, the large stock of non-performing assets is also a problem (Slovenia, Greece, Cyprus, and Portugal). The average European non-performing ratio, around $5 \%$, is high by international standards and exceeds those of the US and the UK. This ratio remains high in the majority of European countries that were most affected by the financial crisis (Constâncio 2016).

The Central and Eastern European (CEE) banking sectors were more resilient before the crisis than Western European ones, and they regained their profitability after the last crisis. Most of them performed well because they were not significantly exposed to toxic assets or sub-prime loans. Some CEE countries (principally Bulgaria and Romania) had a high share of long-term loans denominated in foreign currency and a high non-performing loans ratio (Radulescu 2014). This was largely contributed by the fact that those countries did not rush to reform their banking system, while other CEE countries such as Hungary, Poland, the Czech Republic, and Slovakia were among the first and the most rapid reformers.

The global financial crisis revealed that the Baltic region is exposed to aboveaverage earnings risks. The Baltic states are small, open economies and their economic activities varied a lot during the crisis. These cyclic fluctuations greatly affected the banking sector, raising the level of non-performing loans and lowering the ROA and ROE much below the EU average. The performance of Baltic banking sectors improved after 2011 (Titko et al. 2015).

All of these issues raise concerns over how the European banking systems will perform in the future. If we add the Brexit issue, we have an interesting challenge for this research. The protracted economic problems and the inadequate management of economic policy in the EU increased social discontent that may have eventually contributed to Brexit. The short- and long-run impacts of the decision are difficult to judge, given that the conditions of the exit are not yet known (Váradi et al. 2016).

European banks are undergoing a real-life stress test in the wake of Britain's vote to leave the European Union. Their share prices were already down after the referendum result was announced. Some banking systems that have already 
shown some weaknesses became more unstable after this historical change in the EU. The best examples are Italy and Portugal. Italian banks, as a whole, have a high level of non-performing loans, whose total amount has been rising since the financial crisis. Greek banks also had great problems in maintaining liquidity, profitability, and the level of capitalisation. Although the state has recapitalised its banks three times, it has had almost no effect. Conversely, the German banking system, the leading one in the near past, eventually lost its capitalisation, liquidity, and profitability. These are just a few examples, illustrating that the banking industry is set for many other radical changes after Brexit.

Bearing the above in mind, our aim is to compare the performances of $\mathrm{EU}$ banking systems and underline their strong points and weaknesses right after the Brexit moment (June 2016) and within the framework of the tight new Basel III regulations. We have ranked the EU banking systems using multi-criteria analysis, specifically the PROMETHEE II method. The ranking was performed for all $28 \mathrm{EU}$ countries according to the values of ratios expressing the profitability, the soundness, and the risks undertaken by the banking systems, as they result from many studies that focused on the relation between the performance ratios of the banking systems worldwide. We used the data for the end of the second quarter of 2016, right after UK voted for Brexit and right after the moment when the Italian, Portuguese, German, and Greek banking systems began to signal important liquidity, capitalisation, and debt problems. The weights for these banks' performance determinants have been established using the entropic method to ensure an objective definition of the weights. The use of the PROMETHEE II method enabled the identification of each EU country rank, with the strong points and weaknesses of their banking systems. The main contribution of our research is conducting the multi-criteria analysis for all national banking sectors in the EU area, not only for some selected banks belonging to one national banking system as other authors have done so far.

The paper is organised as follows. Section 2 presents the literature on multicriteria analysis in the banking sector. Section 3 presents the methodology we used. Section 4 discusses the results for the best or poorest ranked EU banking systems. Section 5 concludes.

\section{LITERATURE REVIEW}

The banking system stability is important for the EU because it is considered that the banking systems of member countries have to converge and form a banking union. The existence of a banking union, on the other hand, has an important role in supporting the Single Market, the need for which emerged from the financial 
crisis of 2008 and the subsequent sovereign debt crisis. However, the idea of the European Banking Union (EBU) has not yet been accepted by all EU member states. Member countries of the European Monetary Union (EMU) automatically also become members of the EBU, while EU member countries outside EMU are not eligible to join the EBU. However, these countries may, after notification of a request to the ECB, establish "close cooperation" with the ECB. Bearing this in mind, Vollmer (2016) investigated the consequences of incomplete regulatory integration within a common market and came to the conclusion that EBU failed to integrate all relevant political actors into the common regulatory framework and that CEE countries should reconsider their current position towards EBU membership, given the presently stable financial sectors in these countries. This could change, however, if the present member states of the EBU intensify their cooperation and unify their positions, resulting in a marginalisation of opt-in countries within the ECB and the European Union.

In contrast, some authors advocated necessity of greater integration and coordination among EU banking systems. The study of Schoenmaker - Peek (2014) showed that, at the aggregate level the Baltics, Cyprus, Greece, Ireland, and Spain and Italy in particular were hit by a strong decline in lending in the wake of the financial crisis. The study showed the vulnerability of emerging Europe and peripheral European countries to adverse developments in foreign banking groups from Western Europe. The Western banking systems contracted both on the total banking system and on foreign participation within the total banking system. During the crisis, the concentration of the banking systems decreased in the CEE region, while it increased in the peripheral European countries. Western banks propagated the crisis eastwards by reducing the credit supply to both existing and potential borrowers in emerging Europe, faster than the domestic banks (De Haas et al. 2015). This means that emerging Europe should improve supervisory coordination within the euro zone in the future to prevent the crisis.

Iwanicz-Drozdowska et al. (2016) analysed the costs of bank restructuring measures undertaken in the EU countries during the global financial crisis under the state aid framework. They found that the most important determinant was the level of capital adequacy, while the most cost-consuming tool was the liquidation of a bank. They also concluded that the banking union project within the euro zone and the single rule book in the entire EU may help to treat all banks in a similar way. However, due to limited human resources, supervisors may not be able to conduct on-site and off-site inspections with the required frequency.

Căpraru - Ihnatov (2015) investigated the influence of new member accession on banking performance. They came to the conclusion that new member states (NMSs) had influenced EU-15 bank performances only in terms of net interest margin (NIM), and that the effect was negative. They suggested to authorities a 
better supervision for credit risk and liquidity as well as maintaining a competitive banking environment, and to banks' management to monitor credit risk indicators, optimising costs and diversifying the sources of income.

Some new studies stressed the impact of Brexit on bank performance. This is especially true for members that have drastically opened their banking markets and for those countries that already have some problems with banking system capitalisation, soundness, and liquidity. In order to investigate the impact of Brexit on the EU banking system, Schiereck et al. (2016) analysed the stock and credit default swap (CDS) market reactions around the membership referendum ("Brexit") on June 23, 2016, and the Lehman Brothers bankruptcy filing on September 15. Their conclusion was that the short-term drop in stock prices after the Brexit announcement was more pronounced than after Lehman's bankruptcy, particularly for EU banks. Bearing in mind that shocks like this can have great influence on the EU as a whole, but also on each member country, it is necessary for the ECB to obtain a detailed and comprehensive insight into the current state of the banking system in each country. In this way, the ECB would be able to define measures that are adjusted to some groups of countries with similar characteristics of their banking system and even to each member country.

The application of multi-criteria methods in the comparative analysis of national banking systems is relatively new. There are few papers that used the multicriteria analysis in banking sector research. Most of them are aimed at ranking the selected banks in some national economies according to their performances, expressed by an adequate set of representative indicators. Rosenzweig et al. (2013) used goal programming as a multi-criteria method for ranking the 10 biggest commercial banks in Croatia by three groups of indicators. Similarly, Cetin K. - Cetin E. (2010) ranked 13 Turkish banks according to their financial ratios, using the VIKOR method of multi-criteria analysis. Besides VIKOR, Wu et al. (2009) used also Technique for Order Preference by Similarity to Ideal Solution (TOPSIS) and Simple Average Weight (SAW) to evaluate the performances of three selected banks. The relative weights of the chosen evaluation indexes were calculated by Fuzzy Analytic Hierarchy Process (FAHP). The results indicate that multi-criteria techniques can also be a successful tool for bank management.

Bayyurt (2013) applied TOPSIS, ELECTRE III and Data Envelopment Analysis (DEA), as multi-criteria decision-making methodologies to investigate whether foreign ownership contributes to bank performances in developing countries. The mean ranks of TOPSIS scores and ELECTRE III results were compared for testing the performances of domestic and foreign banks. The results suggested that foreign banks had better performance than domestic ones.

Önder - Hepşen (2013) went one step further and used multi-criteria analysis in combination with time series techniques for forecasting the financial perform- 
ance of Turkish banks. Using the different time series techniques, they predicted the financial performances of 17 banks. After selecting the best forecasting technique, they used the Analytic Hierarchy Process (AHP) method to calculate the weights needed for the application of TOPSIS on selected forecasted bank performances. The same combination of multi-criteria methods was also used by Seçme et al. (2009), Mandic et al. (2014), and Çelen (2014).

One of the papers that use PROMETHEE II method in the analysis of bank performance is a study by Doumpos - Zopounidis (2010). They selected criteria for ranking selected Greek banks that comply with the CAMELS framework. Their overall conclusion was that multi-criteria methods should be used by expert bank analysts as supportive tools in their daily practice for bank performance monitoring and evaluation. These authors also published several other papers regarding the application of multi-criteria methods in banking and finance, e.g. Spathis et al. (2002), Doumpos - Zopounidis (2002), Doumpos et al. (2009), and Gaganis et al. (2010).

The contribution of our paper is the use of the entropy method in combination with the PROMETHEE II method, aiming at ranking the national banking systems (not particular banks) in order to compare their performances and to identify their strong points and weaknesses. Based on an analysis along these lines, any regulatory authority such as the ECB, EBA, etc., can draw conclusions about the current state of EU banking systems and identify some group of countries with similar characteristics of banking system as well as the advantages and disadvantages of each member country. Also, the use of the entropy method indicates the areas where the differences between countries are higher, so authorities should focus on those areas when creating converge measures.

\section{METHODOLOGY}

The Preference Ranking Organisation Method for Enrichment Evaluations (PROMETHEE) is one of the most prominent multi-criteria methods that can be effectively used to solve very complex decision-making problems. The PROMETHEE method has certain advantages in comparison to other well-known MultipleCriteria Decision Making (MCDM) method. The most important is that it has good software support, which enables the additional processing and presentation of the obtained results, such as the PROMETHEE Rainbow, action profiles, and GAIA visual assistance used in this paper. 


\subsection{The PROMETHEE methodology}

In recent years, a large number of methods for decision support have been developed in order to facilitate finding the best compromise solution. One of them is certainly the PROMETHEE family of outranking methods that was developed by Brans (1982) and further extended by Brans - Vincke (1985) and Brans - Mareschal (1995). Several versions of the PROMETHEE method were developed, e.g. PROMETHEE I (partial ranking), PROMETHEE II (complete ranking), PROMETHEE III (ranking based on intervals), PROMETHEE IV (continuous case), PROMETHEE GAIA (geometrical analysis for interactive assistance), PROMETHEE V (MCDA including segmentation constraints), and PROMETHEE VI (representation of the human brain).

The PROMETHEE II method used in this research is an adequate method for solving problems whose aim is a multi-criteria ranking of a final set of alternatives (in this case, EU countries) based on a number of criteria that need to be maximised or minimised. For each observed alternative, this method calculates its value expressed in level of preferences. Thereby, each alternative is evaluated based on the two preference flows: positive preference flow $\varphi+(\mathrm{P})$ and the negative flow of preference $\varphi-(\mathrm{P})$. Next, the PROMETHEE II method accounts net preference flow $\varphi(\mathrm{P})$ as the difference between these two flows. To calculate mentioned flows, the PROMETHEE II method requires the specification of appropriate parameters for each criterion (Brans et al. 1984; Brans - Vincke1985):

1. Direction of preference, minimising or maximising;

2. Weight coefficients, indicating the importance of certain criteria;

3. Adequate preference function, that converts the difference between the two alternatives in the level of preference (Linear, Usual, U-shape, V-shape, Level, and Gaussian);

4. Preference threshold ( $\mathrm{p}$ ), which represents the minimum deviation that a decision-maker considers important for decision-making;

5. Indifference threshold (q), which represents the maximum deviation that a decision-maker considers irrelevant for decision-making;

6. S threshold, which presents the value between the q indifference threshold and the $\mathrm{p}$ preference threshold, and it is used for Gaussian preference function.

The PROMETHEE II methodology is used for ranking $i$ alternatives (where $i=1,2, \ldots \mathrm{m}$ ) according to $j$ criteria (where $j=1,2, \ldots \mathrm{m}$ ), which consist of the following steps (Behzadian et al. 2010):

1. First, deviation based on comparison of a pair of alternatives for the $j$ criteria is calculated

$$
d_{j}(a, b)=g_{j}(a)-g_{j}(b)
$$


where $d_{j}(a, b)$ represent differences between the value of alternative $a$ and $b$ according to each criterion.

2. Next, the chosen function of preferences is used:

$$
P_{j}(a, b)=F_{j}\left[d_{j}(a, b)\right]
$$

where $P_{j}(a, b)$ represents preferences alternative $a$ for each alternative $b$ within every criteria, as a function of $d_{j}(a, b)$.

3. The general index of preferences is calculated:

$$
\forall a, b \in A \pi(a, b)=\sum_{j=1}^{n} P_{j}(a, b) w_{j}
$$

where $\pi(a, b)$ stands for weighted sum $P_{j}(a, b)$ for each criteria, while $w_{j}$ stands for weighted $j$ criteria coefficient.

4. Next, the positive and negative courses of preferences are calculated:

$$
\begin{aligned}
& \varphi^{+}(a)=\frac{1}{m-1} \sum_{x \in A} \pi(a, x) \\
& \varphi^{-}(a)=\frac{1}{m-1} \sum_{x \in A} \pi(x, a)
\end{aligned}
$$

where $\varphi^{+}$represents positive and $\varphi^{-}$negative preferences values for each alternative.

5. Finally, positive and negative courses of preferences are used to calculate net flow of preferences and rank alternatives:

$$
\varphi(a)=\varphi^{+}(a)-\varphi^{-}(a)
$$

where $\varphi(a)$ stands for the net course for each alternative.

On the bias of $\varphi(a)$ value, the countries are ranked from best to the worst, according to all observed criteria.

\subsection{The entropy method}

An appropriate approach for determining the weights of selected indicators is essential for solving MCDM problems. Generally, weights can be classified into subjective weights and objective weights depending on the information source (Hwang - Lin 1987). Subjective weights reflect the subjective judgment or intuition of the decision making (DM), and they can be obtained from the preference information given by the DM directly through interviews, questionnaires, or 
trade-off interrogations. Objective weights are derived from objective information such as the decision matrix (Chen - Li 2011). In order to obtain the quality multi-criteria analysis of banking systems in EU countries, we used the objective definition of weights. The most well-known method of generating objective weights is the entropy method (Hwang - Yoon 1981, Zeleny 1982, and Zou et al. 2006). It first appeared in thermodynamics and was later introduced to information theory by Shannon (1984). It is now widely used in ecology, engineering, medicine, economy, finance, etc., by Guo (2001), Li et al. (2004), Zou et al. (2006), Chuansheng et al. (2012), and Ermatita et al. (2012).

Information entropy is measurement of the disorder degree of a system (Meng 1989). It can measure the amount of useful information with the data provided. When the difference of the value among the evaluating objects on the same indicator is high, while the entropy is small, it illustrates that this indicator provides more useful information, and that the weight of this indicator should be set accordingly high. On the other hand, if the difference is smaller and the entropy is higher, the relative weight should be smaller (Qiu 2002).

The entropy method is conducted as follows (Qiu 2002): The first step in the application of the entropy method is the normalisation of original evaluating matrix. Suppose there are evaluating indicators counted $m$, evaluating objects counted $n$, they form an original indicators value matrix $X=\left(x_{i j}\right)_{m \times n}$

$$
X=\left|\begin{array}{ll}
x_{1_{1}}, x_{1_{2}}, \ldots & x_{1 n} \\
x_{2_{1}}, x_{2_{2}}, \ldots & x_{2 n} \\
x_{m_{1}}, x_{m_{2}}, \ldots & x_{m n}
\end{array}\right| .
$$

The normalisation of this matrix gives Equation (8):

$$
R=\left(r_{i j}\right)_{m \times n}
$$

where $r_{i j}$ is the data of the $i$ th evaluating object on the $j$ th indicator, and $r_{i j} \in[0,1]$.

Among these indicators, which the bigger the better (increasing preference function of the indicator), there are:

$$
r_{i j}=\left(x_{i j}-\min j\left\{x_{i j}\right\}\right) /\left(\max j\left\{x_{i j}\right\}-\min j\left\{x_{i j}\right\}\right) \quad i=1 \ldots m ; j=1 \ldots n
$$

while, the smaller the better (decreasing preference function of the indicator), there are:

$$
\left.r_{(i j=)}\left(\max j\left\{x_{i j}\right\}\right)-x\right)_{i j} /\left(\max j\left\{x_{i j}\right\}-\min j\left\{x_{i j}\right\}\right) \quad i=1 \ldots m ; j=1 \ldots n
$$


The next step is the definition of the entropy. In the $n$ indicators, $m$ evaluating objects evaluation problem, the entropy of $j$ th indicator is defined as:

$$
H_{j}=-k \sum_{i=1}^{m} r_{i j} \ln r_{i j}, \quad j=1,2, \ldots, n
$$

in which $k=1 / \ln \mathrm{m}$ and suppose when $r_{i j}=0, \ln r_{i j}=0$.

Finally, the last step is the definition of the weight of entropy. The weight of entropy of $j$ th indicator could be defined as:

$$
w_{j}=\frac{d j}{\sum_{j=1}^{n} d j}=\frac{1-H_{j}}{\sum_{j=1}^{n}\left(1-H_{j}\right)}
$$

in which $d_{j}=1-H_{j}$ is the degree of diversification for $j$ th indicator $(\mathrm{j}=1 \ldots \mathrm{n})$, and $0 \leq w_{j} \leq 1, \sum_{j=1}^{n} w_{j}=1$.

\subsection{Data and the multi-criteria model formulation}

In order to investigate the banking sector performances of EU countries, a multicriteria analysis has been conducted using the Visual PROMETHEE software package. It has the ability to present the results graphically and thus to provide a more complete picture of the observed problem. The PROMETHEE II method requires the definition of certain parameters for each indicator. We used 9 indicators for 28 countries. Table 1 presents the raw data of our multi-criteria model and identifies the source of our data (Eurgean Banking Authorities).

As it can be seen from Table 1, six indicators should be maximised and three should be minimised. Also, the linear preference function, with appropriate preference threshold and indifference threshold, was applied (as the Visual PROMETHEE software suggested according to the data dispersion). The weights for all observed indicators have been defined by the entropy method. It is interesting to analyse the obtained weights presented in Table 1 . The coverage ratio of non-performing loans and advances has the highest weight coefficient (19.99\%), indicating the highest differences in this area among EU members. The increase in the coverage ratio in most countries is evident (except in Denmark, France, the United Kingdom, Hungary, Latvia, and Spain), probably as the result of higher regulatory scrutiny in relation to the $\mathrm{AQR}$ as well as the negative developments of collateral values leading to an increase in impairment. But the increase is different among member countries (being the highest in Cyprus, Germany, Greece, Luxemburg, Malta, and the Netherlands), which caused the significant dispersion of data for this indicator (EBA 2016). The next indicator according to the value 
Table 1. Evaluation matrix of the national banking systems in $28 \mathrm{EU}$ countries

\begin{tabular}{|c|c|c|c|c|c|c|c|c|c|}
\hline 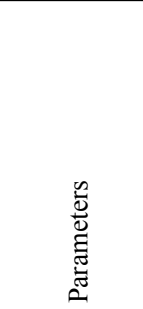 & 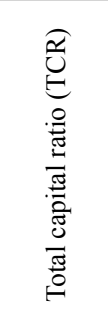 & 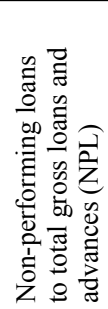 & 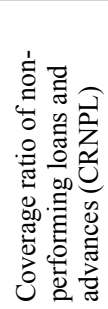 & 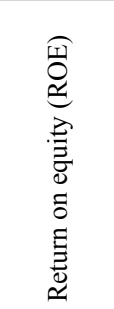 & 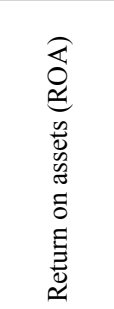 & 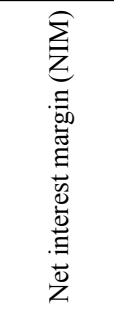 & 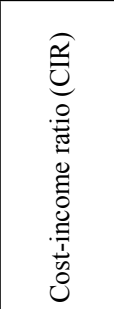 & 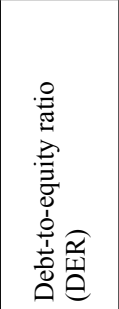 & 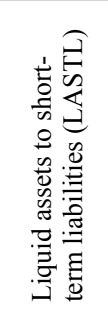 \\
\hline Unit & ratio & ratio & ratio & ratio & ratio & percent & ratio & ratio & ratio \\
\hline $\operatorname{Min} / \max$ & $\max$ & $\min$ & $\max$ & $\max$ & $\max$ & $\max$ & $\min$ & $\min$ & $\max$ \\
\hline Weight & 0.0753 & 0.0934 & 0.1999 & 0.0546 & 0.0706 & 0.1403 & 0.1048 & 0.1752 & 0.0860 \\
\hline $\begin{array}{l}\text { Preference } \\
\text { function }\end{array}$ & Linear & Linear & Linear & Linear & Linear & Linear & Linear & Linear & Linear \\
\hline Thresholds & absolute & absolute & absolute & absolute & absolute & absolute & absolute & \begin{tabular}{|l|} 
absolute \\
\end{tabular} & absolute \\
\hline$q$ & 0.04 & 0.13 & 0.10 & 0.07 & 0.01 & 0.01 & 0.08 & 3.82 & 0.10 \\
\hline $\mathrm{p}$ & 0.09 & 0.24 & 0.24 & 0.14 & 0.02 & 0.02 & 0.20 & 9.15 & 0.20 \\
\hline $\mathrm{s}$ & 0 & 0 & 0 & 0 & 0 & 0 & 0 & 0 & 0 \\
\hline EE & 0.3589 & 0.0155 & 0.2884 & 0.1402 & 0.0235 & 0.0191 & 0.4158 & 5.0525 & 0.2189 \\
\hline SE & 0.2485 & 0.0103 & 0.2824 & 0.1287 & 0.0066 & 0.0099 & 0.4834 & \begin{tabular}{|l|}
19.7247 \\
\end{tabular} & 0.2952 \\
\hline FI & 0.2417 & 0.0146 & 0.2789 & 0.0847 & 0.0043 & 0.0066 & 0.4880 & \begin{tabular}{|l|}
19.0645 \\
\end{tabular} & 0.3058 \\
\hline MT & 0.2191 & 0.0564 & 0.3943 & 0.1322 & 0.0093 & 0.0188 & 0.4701 & \begin{tabular}{|l|}
13.0363 \\
\end{tabular} & 0.5063 \\
\hline NL & 0.2127 & 0.0268 & 0.3635 & 0.0813 & 0.0043 & 0.0153 & 0.6035 & 18.1441 & 0.2012 \\
\hline DK & 0.2117 & 0.0336 & 0.3170 & 0.0940 & 0.0050 & 0.0106 & 0.5637 & \begin{tabular}{|l|}
18.3896 \\
\end{tabular} & 0.2621 \\
\hline HR & 0.2042 & 0.1105 & 0.5916 & 0.1253 & 0.0177 & 0.0317 & 0.4460 & 5.8292 & 0.2582 \\
\hline IE & 0.2009 & 0.1461 & 0.3791 & 0.1019 & 0.0101 & 0.0167 & 0.5589 & 8.9569 & 0.2591 \\
\hline LT & 0.1984 & 0.0450 & 0.3285 & 0.0990 & 0.0119 & 0.0148 & 0.4567 & 8.5124 & 0.1806 \\
\hline $\mathrm{LV}$ & 0.1964 & 0.0348 & 0.3054 & 0.1571 & 0.0192 & 0.0174 & 0.4049 & 8.4927 & 0.3242 \\
\hline SI & 0.1953 & 0.1925 & 0.6625 & 0.1089 & 0.0143 & 0.0251 & 0.5819 & 6.4937 & 0.4694 \\
\hline BG & 0.1951 & 0.1373 & 0.5684 & 0.1936 & 0.0247 & 0.0393 & 0.3445 & 6.9364 & 0.2946 \\
\hline RO & 0.1940 & 0.1214 & 0.6520 & 0.1639 & 0.0187 & 0.0327 & 0.4689 & 7.8702 & 0.4883 \\
\hline $\mathrm{LU}$ & 0.1831 & 0.0104 & 0.4216 & 0.0585 & 0.0044 & 0.0079 & 0.5814 & \begin{tabular}{|l|}
12.7203 \\
\end{tabular} & 0.2319 \\
\hline SK & 0.1817 & 0.0479 & 0.5323 & 0.1540 & 0.0159 & 0.0306 & 0.4607 & 8.9924 & 0.2815 \\
\hline GR & 0.1802 & 0.4687 & 0.4823 & -0.1618 & -0.0181 & 0.0282 & 0.5123 & 7.5009 & 0.0347 \\
\hline $\mathrm{BE}$ & 0.1767 & 0.0359 & 0.4308 & 0.0881 & 0.0050 & 0.0138 & 0.6394 & 16.9117 & 0.2378 \\
\hline $\mathrm{CZ}$ & 0.1749 & 0.0268 & 0.6081 & 0.1512 & 0.0155 & 0.0246 & 0.4295 & 9.4620 & 0.1217 \\
\hline FR & 0.1723 & 0.0393 & 0.5063 & 0.0750 & 0.0045 & 0.0128 & 0.6831 & 16.0599 & 0.1728 \\
\hline $\mathrm{DE}$ & 0.1682 & 0.0263 & 0.3864 & 0.0273 & 0.0014 & 0.0115 & 0.7713 & \begin{tabular}{|l|}
19.2640 \\
\end{tabular} & 0.2237 \\
\hline $\mathrm{HU}$ & 0.1641 & 0.1394 & 0.6170 & 0.1910 & 0.0208 & 0.0426 & 0.6445 & 7.8177 & 0.2829 \\
\hline AT & 0.1612 & 0.0599 & 0.5685 & 0.0846 & 0.0063 & 0.0177 & 0.7111 & 12.1446 & 0.2378 \\
\hline $\mathrm{PL}$ & 0.1578 & 0.0680 & 0.6058 & 0.1014 & 0.0131 & 0.0295 & 0.5144 & 6.8080 & 0.2201 \\
\hline $\mathrm{CY}$ & 0.1577 & 0.4743 & 0.3774 & 0.0515 & 0.0056 & 0.0286 & 0.5141 & 7.9618 & 0.2573 \\
\hline IT & 0.1513 & 0.1640 & 0.4639 & 0.0227 & 0.0016 & 0.0151 & 0.6749 & 13.0651 & 0.1837 \\
\hline ES & 0.1432 & 0.0596 & 0.4483 & 0.0683 & 0.0051 & 0.0222 & 0.5135 & 12.3468 & 0.1968 \\
\hline PT & 0.1190 & 0.1966 & 0.4171 & 0.0455 & -0.0035 & 0.0159 & 0.6494 & \begin{tabular}{|l|}
12.4832 \\
\end{tabular} & 0.1550 \\
\hline GB & 0.1529 & 0.0221 & 0.2987 & 0.0498 & 0.0032 & 0.0149 & 0.6086 & 15.1818 & 0.2280 \\
\hline
\end{tabular}

Source: European Banking Authority: Risk Dashboard Q2 2016. 
of the weight coefficient is the debt-to-equity ratio (17.52\%). This is the result of the fact that risks from a large debt overhang remained high in some countries (Sweden, Germany, Finland, Denmark, the Netherlands, Belgium, and France are above the EU average), while in some such as the CEE countries, the Baltics, Cyprus, Ireland, and Greece were far below the EU average. Significant sovereign exposure in the former countries leads to the elevated vulnerabilities of their banks, worsening the situation in this area.

Generally observed, net interest margin in the EU is low, but differences among countries are still high, resulting in a high weight coefficient (14.03\%). With interest income under pressure in an environment of low interest rates, banks have not yet demonstrated that they can increase fee income. It has greatly affected their profitability, given that growth in loan volumes does not offset margin pressure. In order to increase the profitability in such circumstances, banks have shifted their activities to cost rationalisation by reducing overhead and staff costs as well as increasing automation and digitalisation. As their success in rationalisation was diverse, the cost-income ratio still differs a lot among EU countries, resulting in a relatively high weight coefficient $(10.48 \%)$. A somewhat lower weight coefficient of $9.34 \%$ has been assigned to non-performing loans (NPL) to total gross loans and advances. This indicator remains high in all EU countries, but the differences between countries are moderate compared to the other indicators. Further measures and initiatives to reduce stocks of NPL are being implemented, but they still have to prove their success. The main vulnerabilities result from global economic developments, not least driven by emerging market and political risks (the latter inside and outside the EU), as well as commodity, energy, and shipping exposures.

Liquid assets to short-term liabilities have a weight coefficient of $8.60 \%$. This is a relatively low weight coefficient, given that the remaining indicators and the fact that the fragmentation of asset quality and profitability remained high among jurisdictions. In addition, the usage of central bank funding in part differs significantly between countries. Following the UK referendum, further indications of fragmentation across the single market need to be monitored in order to obtain a satisfactory level of the banking sector liquidity. On the other side, total capital ratio has also a relatively low weight indicator $(7.53 \%)$, indicating that all EU members improved their capitalisation according to the Basel standards. This effect is jointly explained by the growth in capital (mainly driven by higher retained earnings) as well as the slight decrease of risk-weighted asset (RWAs), primarily its market risk components. Finally, profitability indicators, i.e. Return on assets $(7.06 \%)$ and Return on equity (5.46\%), recorded the lowest weight coefficient, although the dispersion among countries has been further widened in Q2 2016, indicating that dispersion in the remaining indicators has been even wider (EBA 2016). 
Table 2. The results of sensitivity analysis

\begin{tabular}{l|c|c|c}
\hline \multirow{2}{*}{ Indicators } & \multirow{2}{*}{ Weights } & \multicolumn{2}{|c}{ Stability intervals } \\
\cline { 3 - 4 } & & Min. & Max. \\
\hline Total capital ratio & 0.0753 & 0.0642 & 0.0754 \\
\hline Non-performing loans to total gross loans and advances & 0.0934 & 0.0813 & 0.0938 \\
\hline Coverage ratio of non-performing loans and advances & 0.1999 & 0.1996 & 0.2134 \\
\hline Return on equity & 0.0546 & 0.0407 & 0.0552 \\
\hline Return on assets & 0.0706 & 0.0554 & 0.0710 \\
\hline Net interest margin & 0.1403 & 0.1399 & 0.1639 \\
\hline Cost-income ratio & 0.1048 & 0.0958 & 0.1049 \\
\hline Debt-to-equity ratio & 0.1752 & 0.1750 & 0.1900 \\
\hline Liquid assets to short-term liabilities & 0.0860 & 0.7970 & 0.0864 \\
\hline
\end{tabular}

While empirical studies have shown that the PROMETHEE II method is rather robust with respect to the values of the preference function thresholds, the weights of the criteria usually have a strong impact on the results of the analysis, especially when there are strongly conflicting criteria. In order to perform some kind of robust analysis of the obtained rankings, Table 2 presents the results of the sensitivity analysis obtained by Visual PROMETHEE software.

The interval of stability defines the limits within which the range of the weight coefficient of the given criteria can be obtained without influencing the obtained result of the PROMETHEE II ranking. Here, it must be taken into consideration that changes of weight can be only done by one criterion, while the relative weights of the other criteria stay the same (Nikolic et al. 2009). It is clear from the result of sensitivity analysis that debt-to-equity ratio and cost-income ratio have the greatest impact on the complete ranking, given that they have a narrow range of weights. The solution is much less sensitive to the weights of the other criteria.

\section{RANKING RESULTS AND DISCUSSION}

The application of the PROMETHEE II method for the reference case scenario produced the following results for the positive preference flows $\varphi^{+}(a)$, the negative preference flows $\varphi^{-}(a)$, and the net preference flows (Table 3).

Table 3 shows that only 11 countries have positive net preference flows, indicating that those countries have better performances of their banking system according to most of the observed criteria. Other countries have disadvantages in the majority of criteria. The ranking results are presented in Figure 1.

The advantages of each country are presented in the top columns and disadvantages are shown below them. In order to get a better insight into how the factors influenced ranking, the country profiles will be discussed in the following. 
Table 3. Preference flows and rankings of EU national banking systems

\begin{tabular}{l|l|l|l|r}
\hline Countries & $\varphi^{+}(a)$ & $\varphi^{-}(a)$ & $\varphi(a)$ & Rank \\
\hline RO & 0.4010 & 0.0051 & 0.3959 & 1 \\
\hline BG & 0.4017 & 0.0121 & 0.3897 & 2 \\
\hline CR & 0.3066 & 0.0135 & 0.293 & 3 \\
\hline HU & 0.3422 & 0.0620 & 0.2802 & 4 \\
\hline SI & 0.3154 & 0.0460 & 0.2694 & 5 \\
\hline PL & 0.2519 & 0.0283 & 0.2236 & 6 \\
\hline SK & 0.2313 & 0.0194 & 0.2119 & 7 \\
\hline CZ & 0.2334 & 0.0439 & 0.1895 & 8 \\
\hline EE & 0.2616 & 0.1151 & 0.1465 & 9 \\
\hline LT & 0.1544 & 0.0987 & 0.0557 & 10 \\
\hline AT & 0.1578 & 0.1121 & 0.0456 & 11 \\
\hline LT & 0.1190 & 0.1296 & -0.0105 & 12 \\
\hline ES & 0.1027 & 0.1216 & -0.0189 & 13 \\
\hline IE & 0.0759 & 0.1005 & -0.0246 & 14 \\
\hline CY & 0.0757 & 0.1062 & -0.0305 & 15 \\
\hline LU & 0.1213 & 0.1909 & -0.0696 & 16 \\
\hline IT & 0.0502 & 0.1647 & -0.1145 & 17 \\
\hline FR & 0.0497 & 0.1917 & -0.142 & 18 \\
\hline GR & 0.0615 & 0.2099 & -0.1483 & 19 \\
\hline SE & 0.1478 & 0.3100 & -0.1623 & 20 \\
\hline BE & 0.0914 & 0.2751 & -0.1836 & 21 \\
\hline & 0.0310 & 0.2209 & -0.1899 & 22 \\
\hline & & & &
\end{tabular}

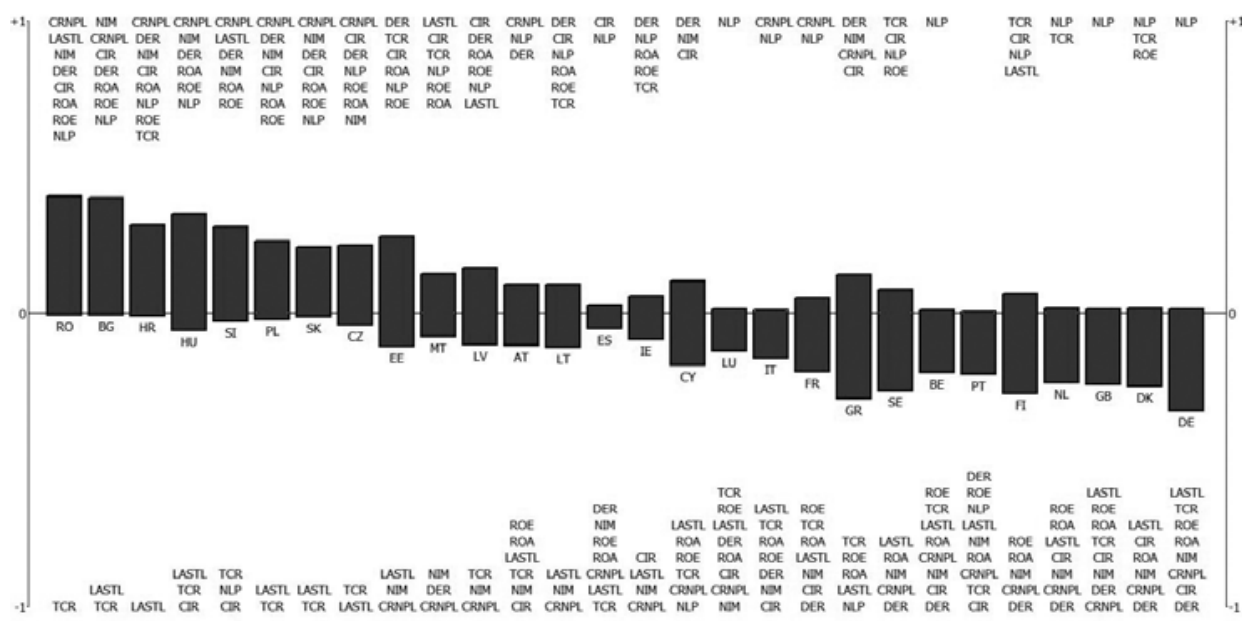

Figure 1. Country rankings with their strong points and their weaknesses 
Table 3. continued

\begin{tabular}{l|c|c|c|c}
\hline Countries & $\varphi^{+}(a)$ & $\varphi^{-}(a)$ & $\varphi(a)$ & Rank \\
\hline PT & 0.0358 & 0.2414 & -0.2056 & 23 \\
\hline FI & 0.0821 & 0.2878 & -0.2057 & 24 \\
\hline NL & 0.0287 & 0.2453 & -0.2166 & 25 \\
\hline GB & 0.0224 & 0.2510 & -0.2286 & 26 \\
\hline DK & 0.0350 & 0.2648 & -0.2298 & 27 \\
\hline DE & 0.0179 & 0.3378 & -0.3199 & 28 \\
\hline
\end{tabular}

\section{Romania}

According to our analysis, as of mid-2016, the Romanian banking system achieved the first position in our ranking. The advantages of the Romanian banking system in mid-2016 are more obvious from Figure 2.

In the first decade of the transition, the Romanian banking system faced a postponed privatisation process. Several banks, especially small banks went bust. Foreign investors control almost $90 \%$ of the total banking assets. Nevertheless, during the crisis, the system pro ed to be vulnerable due to the rising share of nonperforming loans and the high foreign-currency indebtedness of the private sector. A number of banks resized their networks and cut staff. The market has even seen negative margins because of some banks (especially the Greek ones) that paid deposit interest at levels higher than interbank rates to cover their financing needs (Bakor et al. 2012). Although it has a somewhat lower level of capitalisation, it should be noted that the Romanian banking sector has demonstrated its structural stability, being among the few banking sectors in the EU which did not need the state's support during the crisis, while other member states supported their banking systems, primarily through the recapitalisation.

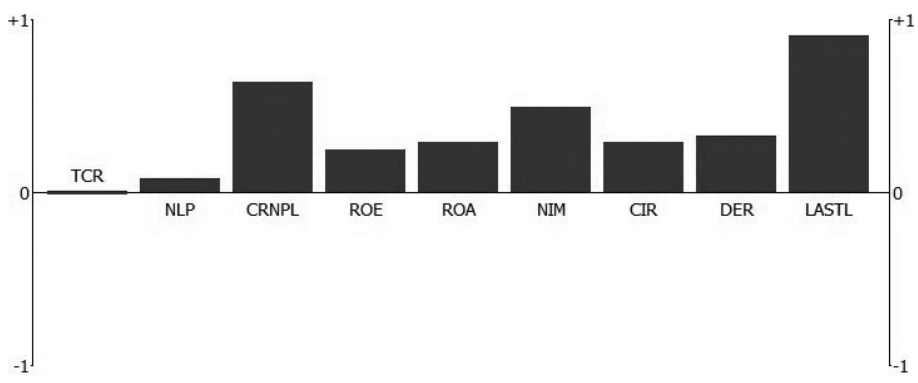

Figure 2. Romania: country profile 
Figure 2 indicates that Romania has the greatest advantage in liquidity. Romania displays a high liquidity ratio, amounting to almost $49 \%$. Only Malta performs better. Strong points of the Romanian banking system are also the net interest margin and the coverage of non-performing loans. The bank net interest margin displays a modest increase in 2015 in comparison to 2014, and in Q2 2016, Romania attained the third position among the EU countries, with a net interest margin amounting to $3.27 \%$. This is the result of the high level of concentration, which has become more pronounced after the crisis. The level of non-performing loans has had the lowest effect on its best position. The Romanian banking system could not close the gap with the levels reached during 2002-2011 for this ratio. Its lowest level was reached in 2014. Provisions to non-performing loans have recorded a real boom after 2005 up to the present. Despite their fluctuant developments and the fact that they decreased slowly after 2013, their level is higher than in the period before the crisis. With a level near $65 \%$, Romania ranks in the second position in Q2 2016 after Slovenia. Debt-to-capital ratio was low in Romania in mid-2016, just like in Poland, Hungary, Bulgaria, Slovenia, and Croatia, almost half of the EU average level of near $15 \%$. At the end, it should be emphasised that the direct effects of Brexit on the Romanian banking system are reduced because the credit institutions with capital coming from the UK are not present on the Romanian banking market.

\section{Bulgaria}

With significant advantages in most of the criteria, Bulgaria has the second position in our rankings.

Bulgaria had the greatest advantage in the area of the net interest margin, followed by the cost-to-income ratio and ROA. Bulgaria's accession to the European Union implied entering "the single" European market and the existence of the single banking license. In this context, foreign banks can enter a member country more easily, which can determine the expansion of competition in local banking activity. Nevertheless, the level of competition in the Bulgarian market is still not satisfactory (Dobre 2015). The relatively high level of concentration has enabled the existing banks to achieve high yields. It is therefore no wonder that this country has achieved a high level of profitability indicators. The net interest margin improved a lot lately (it was around 4\% in 2015) and almost closes the gap with the levels displayed by this ratio before the crisis (between 4.9-5.3\%). Only Hungary ranks better than Bulgaria as far as net interest margin is concerned, with a level of around $4 \%$ in both countries. Bulgaria displays the highest ROA and ROE ratios in the entire EU, with a level of $2.46 \%$ against an EU $0.3 \%$ average for ROA 


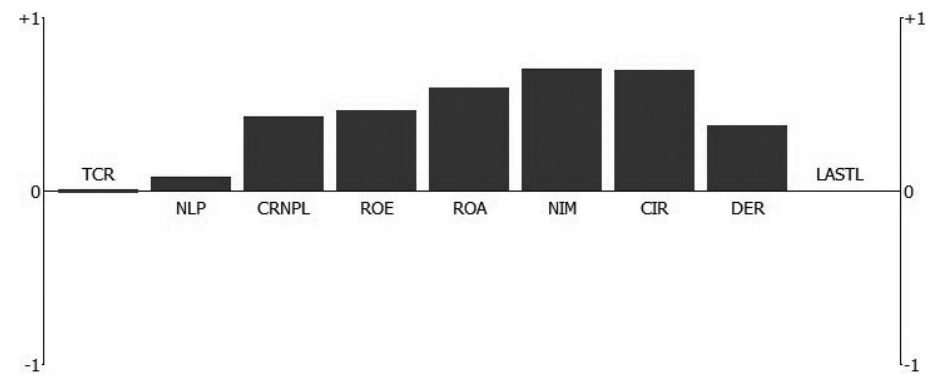

Figure 3. Bulgaria: country profile

and a level of $19.35 \%$ for ROE against an EU 5.6\% average, while Greece and Portugal still have negative values of ROA and ROE. Bulgarian banks cut their costs from $60 \%$ in 2002 to near $34 \%$ by mid-2016. This level is much lower than the EU average of $62 \%$ or the German one that displays the highest cost-income ratio (77\%). This means that banks have cut their operational cost and provided an efficient cost management. This country had the least significant advantage in the area of non-performing loans. Non-performing loans increased a lot during the crisis and their share is still high in Bulgaria in comparison to other CEE countries (although the non-performing loans ratio decreased in mid-2016). Corporate non-performing loans represent the highest proportion of bad debts, significantly exceeding that of households (IMF 2016) and reflecting a hold-and-wait strategy of some local banks, which were reluctant to recognise bad corporate loans and to dispose of them (Kraeva - Clegg 2016). On the other hand, Bulgaria had two disadvantages, namely total capital ratio and liquidity assets ratio, but they have not greatly affected the ranking. Total capital ratio was above the regulatory minimum in mid-2016, but it was still low in comparison to other well-capitalised banking systems. As the authorities successfully managed the stress episode due to spillovers from Greece in 2015, they also succeeded to maintain the stable situation when the Brexit results were announced, indicating that the supervision of the banking sector by the Bulgarian National Bank is satisfactory.

\section{Croatia}

Croatia ranks in 3rd position. After the banking crisis of 1998, which caused the exit of several banks from the market, the Croatian banking system faced a deep transformation process when state-owned banks were privatised and foreign investors gained a market share of more than $90 \%$ of total banking assets. 
The processes of liberalisation and adjustment to international regulatory requirements progressed until the global economic crisis. During the crisis, the banking system showed some weaknesses (profitability ratios decreased, the nonperforming loans increased sharply, indicators of liquidity recorded a decline as result of a faster growth in loans than the growth of deposits, etc.). Although it was affected by the global crisis, the Croatian banking sector did not display losses and it was well capitalised. Reforms of the regulatory and supervisory framework after the EU accession (July 2013) improved efficiency, and thus in mid-2016, all analysed ratios positively contribute to the performance of its banks, except for the liquidity ratio. The short-term cumulative gap, which is usually negative, meaning that the amount of liabilities exceeds the amount of assets expected by banks in the respective maturity period, has been widening from the 2014 and reached the level of 25\% in Q2 2016. It is below the level of the Romanian (48\%), Slovenian (47\%), Bulgarian (29\%), Hungarian and Slovak banking systems (near $28 \%$ ), but its level is still above the EU average, amounting to $21 \%$. Items in the shortest maturity band of up to 15 days, the gap of which increased the most, had the greatest influence on the developments in the short-term cumulative gap. The increase of mismatches in that maturity band is almost exclusively a reflection of the increase in liabilities of the same maturity. These liabilities increased as a result of the increase in sight deposits with transaction and savings accounts and provisions created for the purpose of loan conversion. At the same time, assets of the same maturity went up a little, regardless of noticeable changes in some items that had the opposite sign, such as for instance the decline in net loans and an increase in deposits (Croatian National Bank 2016).

It can be concluded from Figure 4 that the most significant strong point of the Croatian banking system is the coverage of the non-performing loans ratio, followed by the net interest margin, the cost-to-income ratio, and the debt-toequity ratio. It is interesting to mention that despite a relatively high level of non-performing loans, Croatia has one of the highest levels of the coverage of the non-performing loans ratio, which makes the non-performing loans problem much less pronounced. The coverage of the non-performing loans ratio showed a

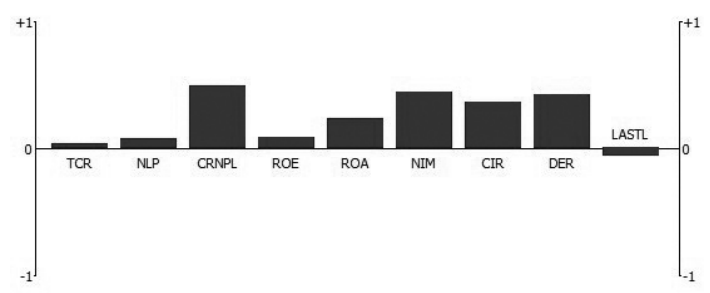

Figure 4. Croatia: country profile 
significant increase during the few past years due to the ageing of existing nonperforming loans and to the rules on the gradual increase in its value adjustments. The coverage ratio places Croatia in the 6th position among EU countries, with a level of 59\%, a much higher level than the EU average level of $43 \%$. Preceding Croatia are Slovenia, Romania, Hungary, the Czech Republic, and Poland. As the structure of funding in the sector has improved (less borrowing from financial institutions, a shift in customer deposits to current accounts), the net interest margin of Croatian banks increased to $3.16 \%$ in mid-2016, placing Croatia in the 4th position among EU countries, while the EU average is much lower (1.48\%). Preceding Croatia are CEE countries such as Hungary, Bulgaria, and Romania. Beside the increase of income, the main drivers of cost-income ratio reduction were a reduction of risk costs and a reduction of operating costs by decreasing the number of operating units and the number of employees, while simultaneously increasing the availability of their services via the ATM network. As a result of such cost rationalisation, the cost-income ratio is low (44.5\%) and well above the EU average of $62.6 \%$. Also, the debt-to-equity ratio is very low in Croatia (5.8\%) and it is to a great extent the result of decline in issuing the debt instruments as the source of finance. Finally, it should be mentioned that Brexit has not directly affected the Croatian banking sector in the short run.

\section{Hungary}

Hungary was considered one of the best performing transition countries for a long time (Fischer - Sahay 2000; Weder 2001), but during the crisis period, the entire Hungarian macroeconomic environment got worse and this affected the profitability of the banking sector. It suffered significant losses for three years (just like the Romania) during the crisis; ROE and ROA rates dropped dramatically. Business volumes declined, while risk costs rose, mainly due to further deterioration in the asset quality of foreign exchange loans (especially the ones denominated in CHF) and mandatory early repayment rules. Many banks tried to reduce operating costs, including closing branches. There were not many mergers and acquisitions at the time because of the regulatory uncertainties. Many banks continued to compete for retail deposits by offering rates above the interbank lending rate. Competition for deposits started to ease after 2012 (Bákor et al. 2012). The programme targeting the conversion of foreign exchange-denominated loans stopped the increase of retail non-performing loans and improved the banking asset quality. It is obvious from Figure 5 that the most important strong point of the Hungarian banking system is the net interest margin, followed by the coverage of non-performing loans, ROE and ROA. During 2002-2007, the net 


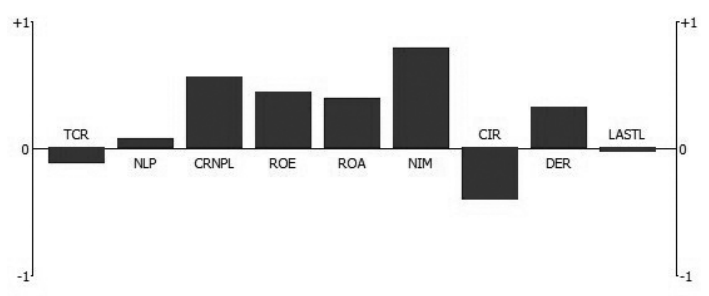

Figure 5. Hungary: country profile

interest margin stayed between $4.5-5.6 \%$. After 2008, it decreased from $4 \%$ to $2 \%$ in 2014 , but it recovered in 2015 at $4.8 \%$ and at $4.3 \%$ at mid-2016. According to this indicator, Hungary ranks first in the entire EU area. Although the level of non-performing loans is the least important advantage of Hungarian banking system, the country has a very high coverage of non-performing loans, enabling it to be among the top five in our ranking. Provisions to non-performing loans ratio fluctuated during the entire period and it reached 59-60\% during 2014-2015. These levels are almost equal to the highest pre-crisis levels of $65 \%$ attained in 2005 and 2007. In mid-2016, this ratio was $61 \%$ and Hungary was $3^{\text {rd }}$ among the EU countries, after Slovenia (66\%) and Romania (61\%). The Hungarian banking sector suffered significant losses during the crisis, and ROE and ROA rates just dropped dramatically. The situation became even more untenable after debt crisis and the conversion of loans denominated in CHF, when Hungarian banks recorded high negative ROE for two consecutive years during the crisis in 20112012 and then the banking system turned negative again in 2014. The ROE of Hungary's banks rose from $-0.1 \%$ in 2015 to $19.1 \%$ in mid-2016. In early 2015 , the government agreed with the European Bank for Reconstruction and Development (EBRD) to decrease, among other taxes, the bank tax to EU levels by 2019, and to transfer all direct and indirect majority equity stakes held in local banks to the private sector by 2017 (Bertelsmann Stiftung 2016). ROA displayed a stable level between $1.5-2 \%$ before the crisis, and after the crisis this ratio decreased at negative levels until 2013. In 2015, it reached 0.22 percent, much lower than the pre-crisis levels. It recovered in 2016 at a level of $2 \%$, ranking Hungary after Estonia (2.4\%) and Bulgaria (2.3\%). On the other hand, Hungary displayed weaknesses in the capital adequacy area (total capital ratio, $-16 \%$, below the EU average), liquidity area (28\%), and cost-income ratio, which is still at high levels (64\%) among CEE countries, just like in Slovenia (58\%) and Poland (51\%), and represents the most pronounced limitation of this banking system. 


\section{Slovenia}

Slovenia differs in some respects from the other countries of the region. In 2003, only a third of the banks' capital belonged to foreign owners. Having started from a more favourable position than the other CEE countries, Slovenia chose not to privatise banks and to limit foreign competition. It should be noted that this strategy proved to be correct, as bank intermediation developed rapidly and no major banking crises occurred for a while (Havrylchyk - Jurzyk 2006).

However, during the economic crisis, Slovenia was transformed from one of the most successful NMSs into one of the most problematic countries. Before 2008, credit activity was extremely high in Slovenia. During the financial crisis, a significant decline in real estate prices provoked a deterioration. It turned out that many loans were inadequately secured, risk management was poor. These led to a decrease in net interest income. Non-performing loans increased at 30\%, while capital adequacy decreased and was below the minimum requested level. Slovenia started to rehabilitate its banking sector by means of a bad bank at the end of 2013. The state ownership of systemic banks and political instability both contributed to delaying the actions taken. Compared with other countries, the fiscal costs of bank rehabilitation in Slovenia were low, but the delay in rehabilitation (which started five years after the crisis erupted) had a negative effect on macroeconomic indicators (Hribernik-Markovic-Tomec 2015).

All Slovenian banks, large state-owned banks in particular, suffered great losses and significantly diminished their balance sheets. The government took further measures to stabilise the banking sector in 2014, which eased liquidity pressures. Confidence in the major state-owned banks returned and there was an inflow of retail funds from the beginning of 2014. Policy measures taken during 2013-2014 facilitated the improvement of the banking funding, while the reduction of the loan allowed banks to repay most of their ECB borrowing. After facing losses during three consecutive years, the Slovenian banking sector returned to profitability in 2014. Net interest margins and profitability started to recover. Improved profitability can be attributed to the significantly lower level of provisions and the growth in net interest income. Slovenia managed to save its state-owned banks mostly with its own funds. In 2014, the Slovenian economy rebounded strongly, but the high level of non-performing loans (mostly in the corporate sector) and low credit demand from creditworthy firms may have implications for the viability of the banking sector in the following years. Credit growth remains negative and banks' profitability can be further threatened (European Commission 2015).

Slovenia has an advantage in the liquidity assets area, not in cost-to-income ratio and non-performing loans area like other CEE countries. The disadvantage in 
the cost-to-income ratio area is the result of a sharp decline of income, although banks reduced impairment and provisioning costs. Owing to the simultaneous decline in non-interest income, which was caused by a contraction in lending activity and a net loss from trading activities, the banking system's gross income declined. As loans contract further, the banks cannot compensate for the loss of net interest income by increasing net non-interest income (Bank of Slovenia 2016). Given that this country is slowly abandoning the practice of soft budget constraints, the high level of non-performing loans in Slovenian banks is not surprising. Also, the banking system liquidity is good and stable primarily due to the high share of Slovenian government bonds in total liquid assets. The greatest impact of Brexit on the Slovenian banking sector is the postponed privatisation of Slovenia's largest bank, the Nova Ljubljanska Banka due to increased market volatility caused by the UK's vote to leave the EU.

\section{The rest of EU-28 countries}

The Baltic States are placed in the middle of our rankings. Estonia is the best (it is placed in the $9^{\text {th }}$ position), followed by Latvia $\left(11^{\text {th }}\right)$, and Lithuania $\left(13^{\text {th }}\right)$. Their advantages are similar to those in the CEE region: non-performing loans, ROA, ROE, cost-to-income ratio, and debt-to-equity ratio. Unlike the CEE countries, the coverage of non-performing loans and the net interest margin are disadvantages of all these countries. They also have disadvantages in the area of capitalisation and liquidity, with some exceptions. Estonia and Lithuania have a significant advantage in the area of capitalisation, especially Estonia which is the first ranked EU country according to the total capital ratio level. All banks operating in Lithuania complied with both the minimum capital adequacy requirement and the combined capital buffer requirement. On the other hand, Latvia has a disadvantage in the capitalisation area, but it ranks well in the liquidity area, which is a disadvantage of the remaining Baltic countries. Generally, the banking systems of these countries are characterised by significant fluctuations, given that they are small open economies and that the major players in their banking sectors are Scandinavian banks (with a market share over $60 \%$ in terms of assets), and thus the shocks from the global financial market are very quickly transferred to the financial markets of these countries.

The remaining European countries are placed from the middle to the end of the rankings. The best ranked countries from this group (positioned in the first half of the rankings) are Malta $\left(10^{\text {th }}\right)$, Austria $\left(12^{\text {th }}\right)$, and Spain $\left(14^{\text {th }}\right)$. The remaining countries are placed in the second half of our rankings. If we consider the European countries that were greatly affected by the last financial crisis, we can 
find Italy $\left(18^{\text {th }}\right)$, Greece $\left(20^{\text {th }}\right)$ and Portugal $\left(23^{\text {rd }}\right)$. All countries in this group have some significant disadvantages, the most common being the coverage of the nonperforming loans ratio, ROA, ROE, the net interest margin, the cost-to-income ratio, and the debt-to equity ratio. Unlike the previous two groups, the strong points vary from country to country. The good performers in the area of total capital ratio are Malta, Ireland, the Netherlands, Sweden, Denmark, and Finland; France, Greece, Italy, and Austria in the area of the coverage of non-performing loans; Malta, Ireland, Sweden, and Denmark in the area of ROE; Greece and Cyprus in the area of net interest margin; Malta, Spain, Cyprus, Greece, Sweden, and Finland in the area of cost-to-income ratio; Austria, Ireland, Cyprus, and Greece in the area of debt-to-equity ratio; Finland and Malta in the area of the liquidity ratio.

In a strongly concentrated banking system (e.g. Finland), insolvency or other serious difficulties at a single large bank will lead to a substantial reduction in lending. Subsidiaries and branches of foreign banks comprise a large part of Finland's banking sector. Finnish banks' deposit deficit - the difference between loans to the public and retail deposits - is one of the largest in the EU (Denmark ranks in the first position). Banks fund their deposit deficits through funding from the financial markets. The relative share of short-term market funding in Finnish banks' funding acquisition has, however, declined in recent years, among others on account of regulatory changes. Housing loans' share of bank lending in Finland is one of the largest in Europe (once again, Denmark ranks in the first position). Large housing market crises often lead to recessions that generate loan losses from corporate lending too, and undermine the Finnish banks' profitability (Bank of Finland 2015). The strong points are capitalisation, liquidity, a relatively low non-performing loans ratio, and the cost-to-income ratio. The weak points are high indebtedness and low profitability.

It is interesting to analyse the very bottom of the rankings, where the four last ranked countries are: the Netherlands, Great Britain, Denmark, and Germany $\left.25^{\text {th }}-28^{\text {th }}\right)$.

The Dutch banking sector is relatively large in size, highly concentrated, and dominated by a small number of large national banks undertaking a wide range of activities. To a large extent, this structure results from the mergers that occurred at the end of the 1980s and in the early 1990s, and from a number of market distortions and the unintended consequences of past policy initiatives. Examples include tax incentives contributing to a large sector size, such as the deductibility of interest payments on mortgages and business loans as well as competitive advantages and implicit state guarantees for banks already enjoying dominant market positions. These encourage banks to grow larger, while discouraging them from specialising in the areas of their particular expertise. Since the start of the 


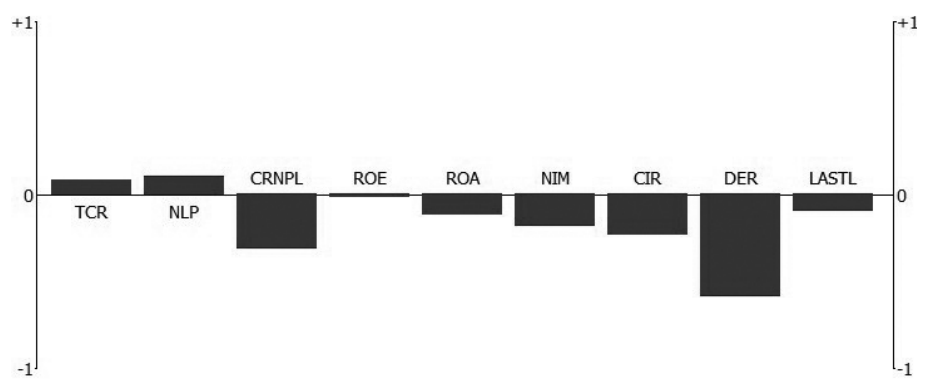

Figure 6. The Netherlands: country profile

crisis, the total size of the Dutch banking sector has decreased. Nevertheless, the sector remains large in proportion to the size of the economy from both a historical and an international perspective (De Nederlandsche Bank 2015).

Public expenditure to provide capital support to banks and insurance companies was significant. Few large financial institutions survived without substantial state support, and state ownership or participation is now extensive. The most challenging vulnerabilities were represented by the high indebtedness of home buyers and the external risks related to banks' cross-border activities. Dutch banks were exposed to US securitised mortgages, in part through their US subsidiaries, and were affected by the tightening of the inter-bank funding market (IMF 2011).

Up to 2015 , banks managed to improve their capital ratios. Driven by a low demand for credit and the disposal of non-core activities, banks have been derisking and de-leveraging their balance sheets. However, banks have not managed to restore profitability to pre-crisis levels. Income has decreased as a result of the decreasing balance sheets, while costs have been high due to restructuring, and increased regulation. Although banks have improved their capital ratios, the current low level of profitability combined with additional regulatory reform has given rise to new challenges (KPMG 2016).

After a significant growth during the crisis, the stock of the non-performing loans recorded a gradual fall during the next few years, as a result of a developed and deep non-performing loans market. Simultaneously, the De Nederlandsche Bank raised capital requirements, so the total capital ratio levels are above minimum requirements and on a track to meet the Basel III requirements. As a result, the Netherlands has strong points in the area of non-performing loans and total capital ratio. All remaining indicators represent the obstacles of the Dutch banking system. The most pronounced among them are the debt-to-equity ratio and the coverage of non-performing loans, while the least significant limitation is ROE. Banks issued a significant number of hybrid debt instruments, which raised the risks. Furthermore, it led to the fall of bank's share prices, resulting in a high 
level of debt-to-equity ratio. According to that indicator, the Netherlands is in $21^{\text {st }}$ position. Also, the slowdown in economic activity influenced the drop of credit activities and lowering the non-performing loans, and the insufficient profitability (resulting in the low level of the net interest margin, ROA and ROE). Given that UK banks are important trading partners for the Netherlands banks, Brexit is certain to impact the Dutch banking system, through market volatility and by raising risks.

Figure 7 indicates that the United Kingdom $\left(26^{\text {th }}\right)$ has an advantage merely in the area of non-performing loans.

For nearly two centuries, the British financial system has been a major centre of global finance and the source of many innovations, in particular in long-term finance and international banking. The rapidly growing scale of the British financial system, its deregulation in 1987, and the recent financial crisis masked structural changes that have made the financial system less "functional" in intermediating resources. Among the changes that led to such developments was the increasing level of leverage in the non-financial sectors of the economy. Domestic sector credit to the private sector as a share of GDP almost doubled during 1997-2007. In the corporate sector, prior to the financial crisis, access to bank debt was easy and at low risk margins. These funds were not channelled into productive investments, but into real estate and financial asset markets. This huge expansion in mortgage lending was accompanied by house price inflation. The borrowings for consumption increased. Consumption fell after the crisis struck and was a major cause of the prolonged recession. The deregulation of the financial system has increased the internationalisation of the financial system that became dominated by foreign financial and banking institutions. Domination by foreign banks and financial institutions makes regulation less effective. This internationalisation provides a conduit through which disturbances in all parts of the world are transmitted to the UK economy and created a dependence on the US Federal Reserve for support in coping with the recent financial crisis through swap agreements (Shabani et al. 2014). The banking crisis was rapidly transmitted to the real economy, with the UK plunging into a sharp recession. After a few years of low credit activities, improved credit conditions in the UK over the last few years have gradually benefited the overall quality of the remaining portfolios, leading to a low non-performing loans ratio, which is the only advantage of its banking system. UK banks sold their non-performing portfolios in order to obtain the "right size" of their balance sheets in response to new capital constrains and regulatory pressures. Although the share of the non-performing loans ratio in total loans has been reduced, the major disadvantage is the low level of the coverage of non-performing loans, predominantly as a result of Brexit. The immediate impact of the Brexit referendum was a period of heightened financial 


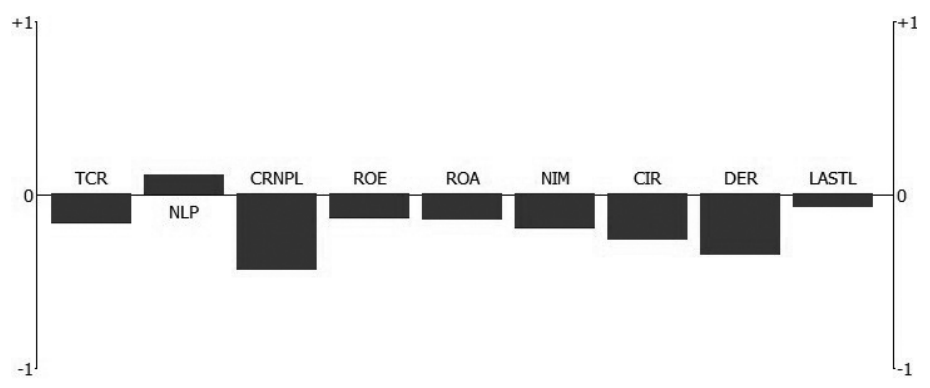

Figure 7. The UK: country profile

market volatility, followed by sharp falls in some UK asset prices and banking sector equity prices, the value of bonds rose significantly and the pound sterling dropped to its lowest value against the US dollar for around 30 years. That also has put profitability under pressure. Bank profitability remained lacklustre, reflecting low interest rates, balance sheet de-risking, declining trading income, and - mainly for the largest banks - high legacy conduct and litigation provisions (IMF 2016). Figure 7 confirms this fact: ROA, ROE and the net interest margin are some of the great weaknesses of the UK banking system. Increase of the debtto-equity ratio and cost-to-income ratio, and the decrease of the total capital ratio are also results of such environment in banking sector.

Denmark is the penultimate country in our rankings. Denmark's banking system is made up of seven systemically important financial institutions (SIFIs) and a large number of small banks. The total assets of the Danish banking system are close to four times the GDP and the three largest banks make up 78\% of total bank assets (OECD 2014).

One of the reasons of the financial crisis in Denmark was the transition to new international accounting principles in 2005, according to which banks no longer had to make provisions for lending on the basis of a demonstrated risk of losses under the prudent accounting principle. Accordingly, the new accounting rules of 2005 did not allow the build-up of "hidden" reserves, reducing thereby the buffers and providing room for increased credit expansion. Another reason was the easing of capital requirements in connection with the implementation of the Basel II capital adequacy rules in 2007, under which some banks chose to utilise the easing for additional lending. Another reason was represented by a high increase of lending some years before the crisis erupted (Abildgren - Thomsen 2011).

Danish banking financing was based on foreign market financing and money market funds as well as bond issuances. This can be described as an altered business model. During 2008-2010, the Danish banking sector faced a crisis as a result of great losses as well as severe liquidity challenges. 


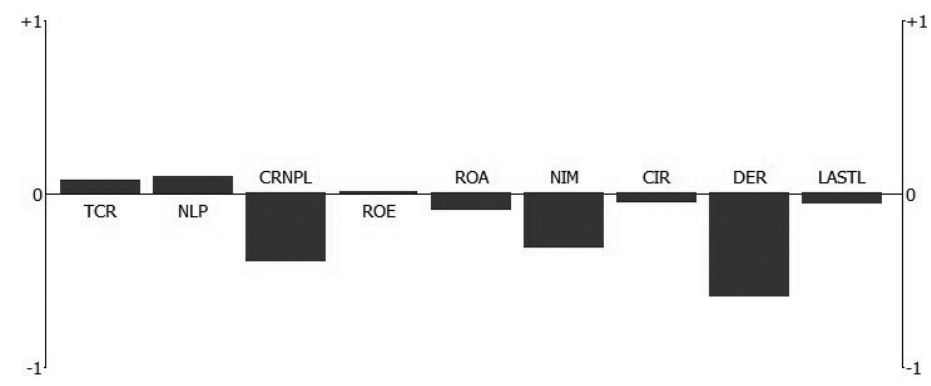

Figure 8. Denmark: country profile

In the face of the global financial crisis and the bursting of the housing market bubble, the authorities responded with six bank packages from October 2008 to October 2013, involving capital injections, liquidity support, and government guarantees. Other measures taken to improve financial stability included the introduction of a special resolution regime and of a credit register to which all banks must report information on their major customers, the reform of the deposit insurance scheme, and the strengthening of regulation and supervision in line with evolving reform at the global and EU levels (OECD 2014). As a result of these reforms, the Danish banking sector has generally become more robust in recent years. Figure 10 indicates that this country has three advantages, namely in the areas of non-performing loans, total capital ratio, and ROE, which are slightly above the EU average. The level of non-performing loans is moderate, amounting to $3.4 \%$ of gross loans, which is far below the EU average (10.2\%). The total capital ratio compares well with those of international peers, but lag behind those of some Nordic ones. Since the beginning of the financial crisis, Danish banks have slowly recovered. They had a negative ROE in 2008 and in 2009, but by mid-2016, this has improved, reaching 9.4\%. The increase in earnings is primarily driven by low loan impairment charges, lower costs, and higher net fee income (this country has the negative interest rates). The remaining indicators reflect the disadvantages of the Danish banking system, among which the most pronounced are the debt-to-equity ratio, coverage of non-performing loans, and net interest margin. Negative interest rates put a pressure on the net interest margin, placing this country in the $24^{\text {th }}$ position according to that indicator. This country occupies the same position by the level of the debt-to-equity ratio. Low demand for new loans caused a low level of the coverage of non-performing loans ratio, placing Denmark in the $23^{\text {rd }}$ position among EU countries by that indicator. Danish banks' lending to households and companies in the United Kingdom is at a low level. Therefore, the systemic risk to Danish banks is limited. 


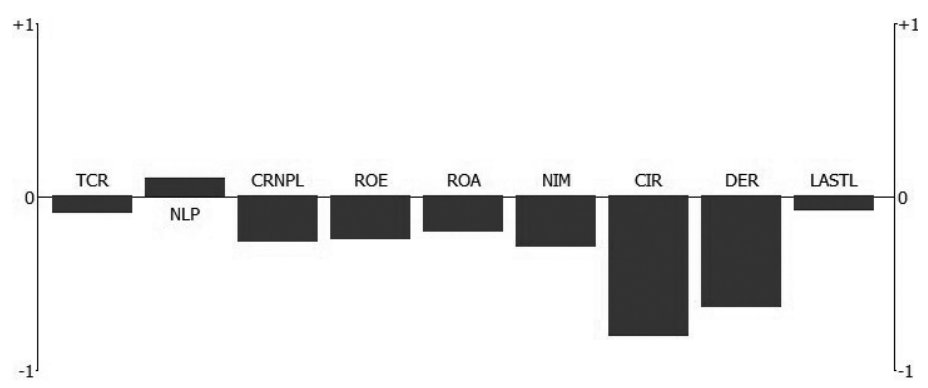

Figure 9. Germany: country profile

Germany is the last ranked country among the EU-28. The German banking system is characterised by an original three-pillar structure: private commercial banks, public banks, and cooperative banks.

During the crisis, the bigger commercial banks came very close to bankruptcy and had to be saved through restructurings. Currently, there are only few major players in the commercial banks sector. The public banking sector is organised territorially: cities and local authorities own local Sparkassen, while Länder (regions) own Landesbanken. The last ones developed many operations during the last decade and they now compete directly with the commercial banks (Finance Watch 2014). In 2009, the capitalisation of banks rose due to a substantial public support and because most banking balance sheets contracted once the crisis erupted. Sparkassen and cooperative banks are likely to be able to meet the new requirements of Basel III, while the regional and larger banks will have to make some adjustments. Although a formal public guarantee was removed in 2001 for public banks, the massive government recapitalisations of 2008 show that there is still an implicit guarantee for the private commercial banks considered as being "too big to fall" (Finance Watch 2014). The NPL ratio increased slightly after 2008 for commercial banks and Landesbanken, but it was lower than in other European countries. This country solved its problem with NPL by physical transfer or distressed assets with the provision of guarantees to cover the losses related to a specific portfolio of assets. These arrangements cap the losses borne by banks through an insurance mechanism until market conditions recover. As a direct result of this strategy, there has been a significant drop in the non-performing loans ratio and it is obvious from Figure 9 that Germany has an advantage in this area. The level of this ratio is $2.6 \%$, almost twice lower than the EU average (5.4\%). The most pronounced disadvantages are in the area of cost-to-income ratio and debt-to-equity ratio, and the least limiting factor is the liquidity assets ratio. This country has the highest cost-to-income ratio among EU counties. It reached the value of $77.1 \%$ and the problem is more obvious if it is compared with the EU 
average, which amounts to 54\%. Namely, higher staff costs and costs aimed at meeting regulatory requirements put a strain on the expenditure side, and the low level of profitability due to the low interest rate and the heavy dependence on interest income put a pressure on the revenue side. It should be emphasised that the cost-income ratio is lower for savings banks and cooperative banks than for the large commercial banks. Germany also displays low performances for debtto-equity ratio, which is mainly a result of Brexit. Market fluctuations in the immediate aftermath of the referendum were characterised by large currency swings and significant equity price declines, particularly in bank stocks, putting pressure on the equity side. Simultaneously, debt recorded a sharp growth due to higher risks, resulting in the second largest debt-to-equity ratio among all EU banking systems, amounting to 19.2, far above the EU average (11.4\%). The British vote to leave the EU had primarily hit large German banks, given their heavy exposure to London.

In order to obtain a better insight in the differences among EU countries, the ranking results are presented in the Geometrical Analysis for Interactive Assistance (GAIA) plane too (Figure 10).

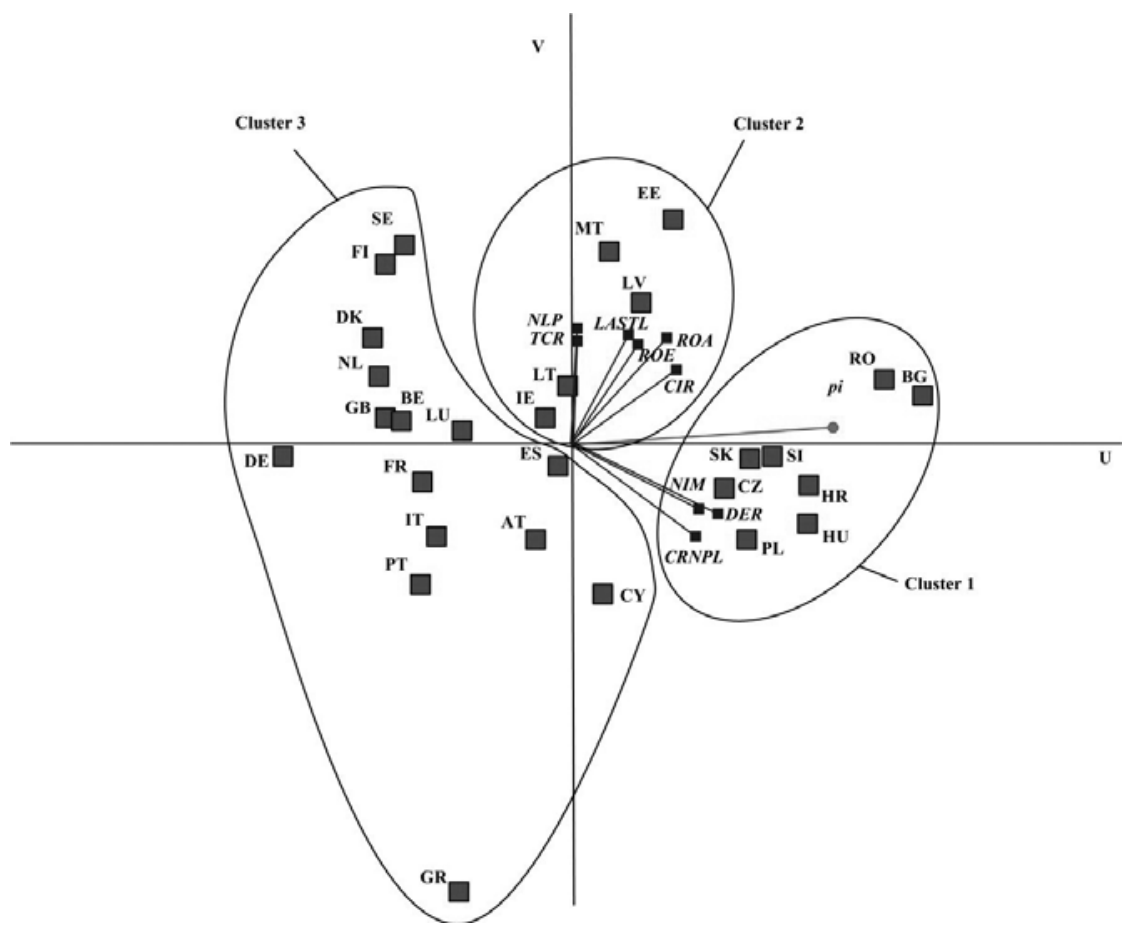

Figure 10. The GAIA plane 
It is obvious from Figure 10 that there are clusters of countries according to their similar characteristics. The GAIA plane offers a graphical interpretation of the PROMETHEE method and shows a clear picture of the observed problem. Based on the GAIA plane, it is possible and easy to determine the discriminative strength of each criterion as well as the aspects of consistency or inconsistency as the indicator of each alternative for all criteria. The alternatives are shown as squares, while the criteria are presented as axes with square endings. The eccentricity of the position of a square criterion represents the strength of the influence of that criterion, while the similarity in preference between certain criteria is defined with almost the same direction of these criteria's axes. The closer to the axe direction of a single criterion, the more the alternative is in accordance with the criteria. The decision stick $p i$ defines the compromising solution in accordance with all the given weight criteria.

Cluster 1 consists of CEE countries, which are the best ranked countries, so they are positioned in the direction of decision stick pi. Bulgaria and Romania, as the best ranked, are farthest from the origin point. The GAIA plane highlights that the main advantages of these countries are the debt-to-equity ratio, coverage of the non-performing loans and net income margin. Brexit has not influenced their banking sectors, given that they are relative close to other EU countries (although their banking sectors are growing fast) and that the UK does not have a significant share in total banking assets.

Cluster 2 consists of the Baltic States, Malta, and Ireland, as the small open banking markets. They are not in the direction of the decision stick $p i$, but they are near it, indicating that they are in the middle of the rankings. These countries are positioned in the direction of all remaining criteria axes, indicating that they have a significant advantage in those areas. The direct impact of Brexit on these countries is small, but there is an indirect effect through big foreign banks (mostly Scandinavian, except in Malta). Their banking markets are more open than those in CEE, but they are characterised by a high level of capitalisation and liquidity that make them relatively robust to shocks in the EU and global banking market.

Cluster 3 includes all remaining countries. They are positioned opposite to decision stick $p i$, indicating that they have disadvantages in most of the observed criteria. The worst ranked Germany is exactly opposite to the decision stick and the farthest from the origin point. These are highly opened and interconnected banking markets that are greatly affected by Brexit, primarily through the sharp drop in share prices, high exposures, and the volatility of exchange rates.

The European Banking Authority published a Risk Dashboard in mid-2016, where the EU banking systems are ranked in the low-risk, medium-risk, or high risk groups, according to the levels achieved for the banking solvability ratios, banking profitability ratios, credit risk ratios, and banking balance sheet structure 
ratios. This report confirmed our cluster analysis and rankings according to the strong points and weak points we have underlined in our analysis. The main findings of this report were as follows:

- Germany, Hungary, Austria, Spain, Italy, and EU area displayed a medium risk in the banking capitalisation area, with a Tier 1 capital ratio between $12-15 \%$, while all the other CEE countries, the Baltic States, the Netherlands, Denmark, and Finland displayed a low risk, with a ratio above 15\%. Portugal displayed a high risk with a Tier 1 capital ratio under $12 \%$.

- Most of the CEE countries displayed a high risk in the non-performing loans area, with levels above 8\% (Slovenia, Hungary, Bulgaria, Romania, and Croatia). Poland, Slovakia, and the EU area displayed a medium risk in the non-performing loans area, with levels ranging between 3-8\%. The Czech Republic, Germany, Denmark, Finland, and the Netherlands displayed a low risk, with levels under $3 \%$.

- In the coverage ratio of non-performing loans area, all CEE countries (except Slovakia that displayed a medium risk) displayed a low risk, with levels above $55 \%$. The EU area displayed a medium risk with a level of $43 \%$. Germany, Denmark, Finland, and the Netherlands displayed a high risk, with levels below $40 \%$.

- In the banking indebtedness area (debt-equity ratio), all CEE countries displayed a low risk, with levels under $12 \%$, while the EU area, Germany, Denmark, Finland, and the Netherlands displayed a high risk, with levels above $15 \%$.

- In the banking cost efficiency area (cost-income ratio), Finland, Romania, Bulgaria, Croatia, Slovakia, and the Czech Republic displayed a low risk, with levels below 50\%. Slovenia, Demark, and Poland displayed a medium risk, with levels ranging between 50-60\%, while Germany, Hungary, the Netherlands, and the EU area displayed a high risk, with levels above $60 \%$.

- In the banking profitability area (ROE), all $8 \mathrm{CEE}$ countries displayed a low risk, with levels above 10\%. Denmark, Finland, and the Netherlands displayed a medium risk, with levels ranging between $6-10 \%$, while the EU area stays in the high-risk area, with a level slightly below $6 \%$, just like Germany that displayed the lowest level of $2.7 \%$.

According to the European Banking Authority classifications, the European banking sectors we ranked in the last positions in our top list display great problems in the indebtedness area and in the coverage of non-performing loans area, while the CEE banking sectors we ranked on the first positions, as they display great problems in the non-performing loans area.

Finally, a general conclusion of our research is that Vollmer (2016), IwaniczDrozdowska et al. (2016), and Schiereck et al. (2016) were right when they em- 
phasised that the ECB should strengthen its capacities in order to obtain a unique approach to bank supervision in all EU countries and that for now, non-EMU members, especially the CEE countries, should reconsider their current position towards European Banking Union membership, given the presently stable financial sectors in these countries, even in the case of Brexit.

\section{CONCLUSION AND POLICY RECOMMENDATIONS}

EU banking systems faced numerous challenges during the last decade. These disturbances were transferred very quickly from one financial market to others. Brexit is one of the last events that will certainly affect all aspects of economy, and especially bank's performances.

In order to define and implement the most effective measures to overcome the current situation, policy-makers in the ECB must identify not just the main weaknesses of each banking system, but also their strong points. This would enable the formulation of a comprehensive and coherent set of measures that will neutralise negative effects and support the strengths of each banking system. A preliminary research along these lines requires the application of multi-criteria analysis, considering that regulators have to consider a broad variety of indicators of systemic importance. This paper is an example of such an analysis. The application of the PROMETHEE II method in combination with the entropy model enabled the examination of each EU banking system and their order by all chosen characteristics immediately after the UK voted to exit the EU.

Our analysis found that CEE banking systems are the best performers according to the observed criteria. These countries have advantages in almost all indicators, except those that indicate their capitalisation and liquidity. The last ranked country is Germany. The problem of the German banking sector is not represented by the bad loans ratio that is under the EU average, but its persistent lack of profitability for a long time, even before the crisis.

It is interesting that almost all EMU members are placed at the end of the ranking. The exceptions are Slovenia, Slovakia, and Estonia, which are in the first third of the ranked countries. There are many reasons for this. A deeper recession in Europe than in the US, doubts over the survival of the EMU and Banking Union, weak domestic governments, the new rules in the European financial market, weaker banking capital positions, and much more determined market interventions by the US Fed against the ECB affected the Europeans banks and they were unable to recover rapidly after the crisis. Still, the supervising authorities of the CEE banking systems should better coordinate their actions with the ECB's actions or with the measures adopted by the Western European supervising authori- 
ties because the main investors in the CEE banking systems come from the euro zone member states. CEE banking countries display a lower exposure to UK banks, and thus Brexit will not greatly affect them. Still, CEE banking systems are exposed to the Italian banks and that could threaten them in the light of the new developments on the Italian banking market.

The main indicator showing the banks' resilience in the face of a potential crisis is bank capitalisation. There have been some improvements in this segment during recent years, due to the growth in the capital (mainly driven by increase of retained earnings) and the slight decrease of risk-weighted assets, primarily its market risk components. Total capital ratio has doubled after the crisis, especially during 2012-2016, but there is still considerable room for further progress. A better capitalisation and an improvement in the banking assets quality levels mask country specific weaknesses, and the German, Portuguese, and even Italian or Greek banking sectors still have work to do in this area.

The ECB should reassess its regulatory approach and the rules about state aid should not be relaxed as a result of the recent crisis in Italian or Portuguese banking sectors. The US recapitalised its banks, bad loans were written down, and a new regulatory framework was designed. Europe did not do this and if it refuses to do so, Brexit can prove to be a financial catastrophe. Brexit will reduce the profitability of UK subsidiary and branches and will cause uncertainty over the business model in the short run.

Another great problem is represented by the fact that some of the European banking sectors still have high levels of non-performing loans (Slovenia, Greece, Cyprus, and Portugal), which restrict loan growth and decrease banking profitability. Some of them could further improve their legal frameworks in order to deal with the non-performing loans. Also, most of them do not have a sufficiently developed and deep non-performing loans market, therefore policy-makers in these countries should, with the assistance of the EBC, establish institutions and regulations necessary for the development of that financial market segment.

Finally, the profitability of banking sectors, especially in the Western European countries, is not on the satisfactory level. Namely, the ECB has tried to boost the recovery of the EU economies by low interest rates, a strategy that has had a greater impact on banking sectors with tougher competition. In this sense, the new regulatory and macroeconomic environment has put pressure on their profitability because for the large banks in the EU area, net interest income makes up, on average, more than half their total income. The deterioration in banks' profitability after Brexit is set to last for longer. Thus, banks will need to adopt more aggressive cost management strategies than in the past and to focus on increasing their other revenues (from fees gained by releasing new products or attracting new clients) in order to obtain profitable business in the future. 


\section{REFERENCES}

Abildgren, K. -Thomsen, J. (2011): A Tale of Two Danish Banking Crises. Monetary Review, 1st Quarter, Part 1: 121-142, Danmarks.

Bank of Finland (2015): Concentrated Banking System Amplifies Banking Crisis. Bulletin, 2/2015 (Available online at https://helda.helsinki.fi/bof/bitstream/handle/123456789/13774/ bulletin215_6.pdf?sequence=1, accessed on 10th April 2017).

Bank of Slovenia (2016): The Financial Stability Review. Ljubljana, Slovenia.

Bákor, K. - Dietz, M. - Kincses, A. - Shvakman, I. (2012): Eastern European Banking: Time to Shift Gears. Banking and Securities (Europe). McKinsey \& Company.

Bayyurt, N. (2013): Ownership Effect on Bank's Performance: Multi Criteria Decision Making Approaches on Foreign and Domestic Turkish Banks. Procedia - Social and Behavioral Sciences, 99(6): $919-928$.

Behr, P. - Schmidt, R. H. (2015): The German Banking System: Characteristics and Challenges. White Paper, No. 32, Research Center SAFE, Goethe University, Frankfurt.

Behzadian, M. - Kazemzadeh, R. B. - Albadvi, A. - Aghadasi, M. (2010): PROMETHEE: A Comprehensive Literature Review on Methodologies and Applications. European Journal of Operational Research, 200(1): 198-215.

Bertelsmann Stiftung (2016): Hungary Country Report. (Available online at https://www.btiproject.org/fileadmin/files/BTI/Downloads/Reports/2016/pdf/BTI_2016_Hungary.pdf, accessed on 10th January 2017).

Brans, J. - Mareschal, B. (2005): PROMETHEE Method. In: Greco, S. (ed.): Multiple Criteria Analysis - State of the Art Surveys: International Series in Operations Research and Management Sciences. New York: Springer, pp. 163-195.

Brans, J. P. (1982): L'ingenierie de la Decision. Elaboration d'Instruments d'Aide a la Decision. Methode PROMETHEE. In: Nadeau, R. - Landry, M. (eds): L'aide a la Decision: Nature, Instruments et Perspectives Davenir. Quebec, Canada: Presses de Universite Laval, pp. 183-214.

Brans, J. P. - Mareschal, B. (1994): The PROMCALC \& GAIA Decision Support System for Multicriteria Decision Aid. Decision Support Systems, 12(4-5): 297-310.

Brans, J. P. - Mareschal, B. (1995): The PROMETHEE VI Procedure: How to Differentiate Hard from Soft Multicriteria Problems. Journal of Decision Systems, 4(3): 213-223.

Brans, J. P. - Vincke, P. (1985): A Preference Ranking Organization Method (The PROMETHEE Method for Multiple Criteria Decision Making). Management Science, 31(6): 647-656.

Brans, J. P. - Mareschal, B. - Vincke, Ph. (1984): PROMETHEE: A New Family of Outranking Methods in Multi-Criteria Analysis. In: Brans, J. P. (ed.): Operational Research '84. Amsterdam: North-Holland. pp. 477-490.

Căpraru, B. - Ihnatov, I. (2015): Determinants of Bank's Profitability in EU15. Scientific Annals of the Alexandru Ioan Cuza University of Iassi Economic Sciences, 62(1): 93-101

Celen, A. (2014): Comparative Analysis of Normalization Procedures in TOPSIS Method with an Application to Turkish Deposit Banking Market. Informatica, 25(2): 185-208.

Cetin, K. - Cetin, I. E. (2010): Multicriteria Analysis of Banks Performance. International Journal of Economics and Finance Studies, 2(2): 73-78.

Chen, T. Y. - Li, C. H. (2011): Objective Weights with Intuitionistic Fuzzy Entropy Measures and Computational Experiment Analysis. Applied Soft Computing, 11(8): 5411-5423.

Chuansheng, X. - Dapeng, D. - Shengping, H. - Xin, X. - Yingjie, C. (2012): Safety Evaluation of Smart Grid Based on AHP-Entropy Method. Systems Engineering Procedia, 4: 203-209. 
Constâncio, V. (2016): Challenges for the European Banking Industry. Presentation at the Conference on "European Banking Industry: What's Next?" University of Navarra, Madrid, 7 July 2016.

Dobre, C. (2015): Concentration in the Banking Sector in Romania and Bulgaria. Ovidius University Annals, Economic Sciences Series, 15(1): 75-79.

Doumpos, M. - Zopounidis, C. (2002): Multi-Criteria Classification Methods in Financial and Banking Decisions. International Transactions in Operational Research, 9(5): 567-581.

Doumpos, M. - Zopounidis, C. (2010): A Multicriteria Decision Support System for Bank Rating. Decision Support Systems, 50(1): 55-63.

Doumpos, M. - Marinakis, Y. - Marinaki, M. - Zopounidis, C. (2009): An Evolutionary Approach to Construction of Outranking Models for Multicriteria Classification: The Case of the ELECTRE TRI Method. European Journal of Operational Research, 199(2): 496-505.

Ermatita, Hartati, S. - Wardoyo, R. - Harjoko, A. (2012): ELECTRE-Entropy Method in Group Decision Support System Modelto Gene Mutation Detection. International Journal of Advanced Research in Artificial Intelligence, 1(1): 58-63.

European Bank Authority (2016): Dynamics and Drivers of Non-Performing Exposures in the EU Banking Sector. EBA Report, 22 July 2016, London.

European Banking Authority (2016): Risk Dashboard Q2-2016 (Available online at https://www. eba.europa.eu/risk-analysis-and-data/risk-dashboard, accessed on 21st November 2016).

European Commission (2015): Country Report Slovenia 2015. Commission staff working document. Gaganis, C. - Pasiouras, F. - Doumpos, M. - Zopounidis, C. (2010): Modelling Banking Sector Stability with Multicriteria Approaches. Optimization Letters, 4(4): 543-558.

Guo, C. Z. (2001): Study on the Evaluating Method of Entropy Coefficient for Stock Investment Value [J]. Nankai Economics Studies, 5: 65-67.

De Haas, R. - Korniyenko, R. Y. - Pivovarsky, A. - Tsankova, T. (2015): Taming the Herd? Journal of Financial Intermediation, 24(3): 325-355.

Hassan, F. (2014): Finance Watch, a View from Germany - How the Three-Pillared German Banking System has Got through the Crisis. (Available at http://www.finance-watch.org/hot-topics/ blog/851-view-from-germany-1, accessed on 9th December 2016).

Havrylchyk, O. - Jurzyk, E. (2006): Profitability of Foreign and Domestic Banks in Central and Eastern Europe: Does the Mode of Entry Matter? LICOS Centre for Transition Economics, Discussion Paper, No. 166.

Härle, P. - Lüders, E. - Pepanides, T. - Pfetsch, S. - Poppensieker, T. - Stegemann, U. (2010): Basel III and European Banking: Its Impact, How Banks Might Respond, and the Challenges of Implementation. McKinsey Working Papers on Risk, November, 26: 1-28. (Available at C:/ Users/BVB09/Downloads/26_Basel_III_and_European_banking.pdf, accessed on 12th January 2017).

Hribernik-Markovic, T. - Tomec, M. (2015): Bad Bank and Other Possible Banks' Rescuing Models - the Case of Slovenia. Annals of the Constantin Brâncuşi University of Târgu Jiu, Economy Series, 1(1): 128-141.

Hwang, C. L. - Lin, M. J. (1987): Group Decision Making under Multiple Criteria: Methods and Applications. Berlin: Springer Verlag.

Hwang, C. L. - Yoon, K. (1981): Multiple Attribute Decision Making-Methods and Applications. A State-of-the-Art Survey. New York: Springer Verlag.

IMF (2011): Kingdom of the Nederlands Financial System Stability Assesment. IMF Country Report, No.144. Washington, D.C. (Available at http://www.imf.org/en/Publications/CR/ Issues/2016/12/31/Kingdom-of-Netherlands-Netherlands-Financial-System-Stability-Assessment-24986, accessed on 10th April 2017). 
IMF (2016): Bulgaria: Selected Paper Issues. IMF Country Report, No. 345. Washington, D.C. Iwanicz-Drozdowska, M. - Smaga, P. - Witkowski, B. (2016): Bank Restructuring in the EU: Which Way to Go? Journal of Policy Modelling, 38(3): 572-586.

Košak, M. - Zajc, P. (2006): Determinants of Bank Efficiency Differences in the New EU Member Countries. Financial Stability Report, Expert Papers. Ljubljana: Bank of Slovenia.

KPMG (2016): The State of Dutch Banks in 2015. Adjusting to the New Reality. KPMG Advisory. (Available at https://assets.kpmg.com/content/dam/kpmg/pdf/2016/04/The-state-of-Dutchbanks-in-2015-14-07-2016.pdf, accessed on 10th April 2017).

Kraeva, K. - Clegg, R. (2016): Bulgaria: Reading between the Lines of the Banking System Assessment. Wolf Theiss Client Alert, August 2016. (Available at http://www.wolftheiss.com/filead$\mathrm{min} / \mathrm{content} / 6$ news/clientAlerts/2016/2016_Q3/160819_CA_Reading_Between_the_Lines of the_Banking_System_Assesment_Bulgaria.pdf, accessed on 10th April 2017).

Li, X. - Li, Y. - Gu, Z. - Yang, W. (2004): Competitive Situation Analysis of Regional Logistics Development based on AHP and Entropy Weight. Journal of Southeast University, 34(3): 398-401.

Mandic, K. - Delibasic, B. - Knezevic, S. - Benkovic, S. (2014): Analysis of the Financial Parameters of Serbian Banks through the Application of the Fuzzy AHP and TOPSIS Methods. Economic Modelling, 43: 30-37.

Meng, Q. S. (1989): Information Theory [M]. Xi'An Jiaotong University Press, China: 19-36.

Nikolic, Dj. - Jovanovic, I. - Mihajlovic, I. - Živković, Ž. (2009): Multi-Criteria Ranking of Copper Concentrates according to Their Quality - An Element of Environmental Management in the Vicinity of Copper - Smelting Complex in Bor, Serbia. Journal of Environmental Management, 91(2): 509-515.

Obradović, S. - Fedajev, A. - Nikolic, D. (2012): Analisys of Business Environment Using the Multi-Criteria Approach - Case of Balkan's Transition Countries. Serbian Journal of Management, 7(1): 37-52.

OECD (2014): OECD Economic Surveys - Denmark Overview. Paris.

Önder, E. - Hepşen, A. (2013): Combining Time Series Analysis and Multi Criteria Decision Making Techniques for Forecasting Financial Performance of Banks in Turkey. International Journal of Latest Trends in Finance and Economic Sciences, 3(3): 530-555.

Qiu, W. H. (2002): The Entropy of Decision and Application of Management [M]. China Machine Press: 193-196.

Rădulescu, M. (2014): Developments of the Banking Systems in Central and Eastern Europe. Berlin: Lambert Academic Publishing.

Rosenzweig, V. V. - Volarević, H. - Varović, M. (2013): A Multi-Criteria Analysis of the Banking System in the Republic of Croatia. Journal of Theory and Practice, 37(4): 403-422.

Schiereck, D. - Kiesel, F. - Kolaric, S. (2016): Brexit: (Not) Another Lehman Moment for Banks? Finance Research Letters, 19: 291-297.

Seçme, N. Y. - Bayrakdaroğlu, A. - Kahraman, C. (2009): Fuzzy Performance Evaluation in Turkish Banking Sector Using Analytic Hierarchy Process and TOPSIS. Expert Systems with Applications, 36(9): 11699-11709.

Shabani, M. - Toporowski, J. - Tyson, J. (2014): The Financial System and Economic Policy in the UK: Problems of Internationalisation. In: Financial Systems in Financial Crisis - An Analysis of Banking Systems in the EU. Intereconomics, ZBW - Leibniz Information Centre for Economics, Germany, pp.: 70-76 (Available at https://www.ceps.eu/system/files/IEForum22014. pdf, accessed on 9th April 2017).

Shannon, C. E. (1984): A Mathematical Theory of Communication. The Bell System Technical Journal, 27(3): 379-423. 
Schoenmaker, D. - Peek, T. (2014): The State of the Banking Sector in Europe. OECD, Economics Department, Working Paper, No. 1102.

Spathis, C. - Doumpos, M. - Zopounidis, C. (2002): Detecting Falsified Financial Statements: A Comparative Study Using Multicriteria Analysis and Multivariate Statistical Techniques. European Accounting Review, 11(3): 509-535.

Titko, J. - Skvarciany, V. - Jureviciene, D. (2015): Drivers of Bank Profitability: Case of Latvia and Lithuania. Intellectual Economics, 9(2): 120-129.

Váradi, B. - Várnai, T. - Virág, B. (2016): Brexit: The End or the Beginning of a Long Road. Acta Oeconomica, 66(S1): 93-110.

Vollmer, U. (2016): The Asymmetric Implementation of the European Banking Union (EBU): Consequences for Financial Stability. International Journal of Management and Economics, 50: $7-26$.

Weder, B. (2001): Institutional Reform in Transition Economies. IMF Working Paper, No. 114.

Wu, H. - Tzeng, G. - Chen, Y. (2009): A Fuzzy MCDM Approach for Evaluating Banking Performance Based on Balanced Scorecard. Expert Systems with Applications, 36(6): 10135-10147.

Zeleny, M. (1982): Multiple Criteria Decision Making. New York: McGraw-Hill.

Zou, Z. - Yun, Y. - Sun, J. (2006): Entropy Method for Determination of Weight of Evaluating Indicators in Fuzzy Synthetic Evaluation for Water Quality Assessment. Journal of Environmental Sciences, 18(5): 1020-1023. 